\title{
Karakterisasi Molekuler Isolat-Isolat Penyebab Bulai (Peronosclerospora spp) Pada Tanaman Jagung Berbasis Simple Sequence Repeat (SSR)
}

\author{
Hikmahwati $^{1}$, Tutik Kuswinanti ${ }^{2}$, Melina $^{3}$ \\ ${ }^{1}$ Program Studi Agroteknologi Universitas Al Asyariah Mandar \\ ${ }^{2}$ Program Studi Agroteknologi Universitas Hasanuddin) \\ ${ }^{3}$ Program Studi Agroteknologi Universitas Hasanuddin) \\ hikmawt00@yahoo.co.id
}

\begin{abstract}
Abstrak
Karakterisasi Molekuler Isolat-Isolat Penyebab Bulai (Peronosclerospora spp.) pada Tanaman Jagung Berbasis Simple Sequence Repeat (SSR).Penelitian ini bertujuan untuk mengetahui (1) spesies Peronosclerospora spp yang diperoleh dari beberapa lokasi di Indonesia dan (2) keragaman genetik dan pengelompokkan antara isolat Peronosclerospora spp. yang diperoleh dari beberapa lokasi di Indonesi. Penelitian ini dilaksanakan di Laboratorium Balai Penelitian Sereal (Balitsereal) Kabupaten Maros, Sulawesi Selatan dan di Pusat Kegiatan Penelitan Universitas Hasanuddin. Isolat yang digunakan berasal dari Medan, Kediri dan Maros. Metode karakterisasi dilakukan secara molekuler dengan metode SSR. Hasil pengamatan dengan metode SSR efektif digunakan dalam studi keragaman genetik Peronosclerospora spp., Analisis kluster dengan UPGMA menghasilkan 3 kelompok, kelompok I terdiri dari 3 isolat asal Kediri, kelompok II terdiri dari 3 isolat asal Medan dan kelompok III terdiri dari 3 isolat asal Maros. Berdasarkan karakterisasi dan analisis kluster isolat dari 3 lokasi yang berbeda memiliki kemungkinan adalah spesies yang berbeda
\end{abstract}

Keywords : Jagung, Peronosclerospora spp, Ciri morfologi, Karakterisasi molekuler, SSR

\section{Pendahuluan}

Salah satu hambatan utama dalam pengembangan jagung adalah adanya gangguan hama dan penyakit. Penyakit bulai (downey mildew), merupakan penyakit utama pada tanaman jagung, karena tanaman yang tertular tidak menghasilkan biji sama sekali. Di lapangan terdapat beberapa laporan yang menyatakan bahwa kehilangan akibat penyakit bulai dapat mencapai $100 \%$ (Sujono, 1988, Wakman et al., 2002, Yasin et al., 2008).

Bulai di Indonesia yang telah diidentifikasi disebabkan oleh tiga spesies yaitu $P$. maydis, $P$. philippinensis dan $P$. sorghi. $P$. maydis ditemukan menyerang tanaman jagung di pulau Jawa dan Kalimantan, P. sorghi ditemukan di pulau Sumatera dan $P$. phillippinensis awalnya meyerang di Minahsa, Sulawesi Utara (van Hoof 1953) dan saat ini dolaporkan menyerang tanaman jagung di pulau Sulawesi, dan penyebaran spesiesnya sudah teridenfikasi di 18 kabupaten/propinsi di Indonesia (Wakman et al. 2006).,). Identifikasi Peronosclerospora spp. dilakukan berdasarkan ciri morfologi seperti bentuk atau ukuran spora yang dimiliki.

Adanya perbedaan respon penyakit terhadap beberapa kultivar inang termasuk pada varietas tahan bulai yang berekembang saat ini diduga menimbulkan perubahan pada tingkat spesies atau pada tingkat patotipe dan adanya perbedaan beberapa hasil penelitan pada identifikasi secara morfologi yang pernah dilakukan sehingga perlu dilakukan karakterisasi secara morfologi untuk melihat bentuk morfologi Peronosclerospora spp di di beberapa wilayah Indonesia saat ini, seperti di Medan (Sumtera Utara), di Kediri (Jawa Timur) dan di Maros (Sulawesi Selatan) yang diduga memiliki 3 spesies yang berbeda. Menurut Wakman et al., (2006) di Indonesia terdapat 3 spesies penyebab penyakit bulai pada tanaman jagung yaitu $P$. maydis yang tersebar di pulau Jawa dan Kalimantan, $P$. philippinensis yang tersebar di pulau Sulawesi dan $P$. sorghi yang tersebar di pulau Sumatera.

Keragaman struktur populasi $P$. sorghi telah diidentifikasi berdasarkan karakter morfologi dan patotipenya. Perbedaan patotip ditandai dengan adanya perbedaan respon penyakit pada beberapa kultivar inang yang berbeda (Bock et al., 2000; Bock et al., 1998). Metode konvensional untuk mendeteksi perbedaan patotipe bulai yang menyerang tanaman sereal tidak cukup akurat untuk digunakan didalam mengkarakterisasi organisme parasit obligat seperti pada patogen tanaman karat dan bulai, yang tidak dapat dikulturkan, karena pada iklim tropis gejala dari Peronosclerospora spp. sulit dibedakan.

Adanya perbedaan patotipe, gejala yang sulit dibedakan dan perbedaan beberapa hasil penelitan pada identifikasi secara konvensial ini menunjukkan adanya kelemahan pada metode identifikasi konvensional. Metode konvensional yang berdasarkan ciri morfologi dan patotipe kurang akurat akibat adanya pengaruh perubahan-perubahan lingkungan. Menurut Smith et al. (1997), karakter-karakter morfologi sering tidak menggambarkan hubungan genetik akibat adanya interaksi lingkungan dan sejumlah kontrol genetik yang 
tidak diketahui, sehingga perlu dilakukan karakterisasi molekuler untuk lebih mendapatkan hasil yang akurat didalam mengkarakterisasi terhadap perbedaan spesies dan struktur populasi Peronosclerospora spp di Indonesia.

Kemajuan di bidang bioteknologi utamanya dibidang biologi molekuler menyebabkan variabilitas genetik suatu populasi dapat diamati pada tingkat protein, isoenzim, dan tingkat DNA. Analisis DNA memiliki efisiensi dan keakuratan yang tinggi sehingga dapat membantu dalam identifikasi dan determinasi keragaman genetik cendawan Peronssclerospora spp. Menurut Albert et al. (2002), untuk identifikasi dan determinasi cendawan yang lebih detail dapat menggunakan penciri DNA.

Beberapa penanda molekuler yang telah digunakan untuk mendeteksi perbedaan antara spesies penyebab bulai adalah dengan teknik RFLP (Restriction fragment length polymorphism) yang berguna untuk mendeteksi variasi pada tingkat DNA, pemetaan dan pencirian gen. Namun demikian metode ini memiliki kelemahan karena menghasilkan sedikit perbedaan pola yang dapat dideteksi pada isolat $P$. sorghi, sama halnya dengan ITS-2 (Internal Transcribed Spacer) hanya menghasilkan sebuah transcribed spacer di dalam gen ribosom yang memiliki ukuran yang berbeda (Yao et al., 1992). ITS-2 merupakan penanda molekuler yang dapat digunakan untuk mengidentifikasi spesies, yang dapat membedakan ukuran gen pada ribosom. Penggunaan RAPD-PCR juga dapat digunakan untuk mengetahui adanya polomorfisme pada SDM (Sorghum Downey Mildew) pada tingkat patotipe dengan menggunakan banyak primer pendek (10 mer). Masalah besarnya adalah adanya amplifikasi pita yang tidak konsisten dengan hasil yang bervariasi meskipun pada eksperimen yang sama (Perumal et al., 2006). Untuk itu diperlukan sebuah metode yang sifatnya stabil dan konsisten untuk proses karakterisasi yang lebih akurat, sehingga dikembangkan penanda mikrosatelit.

Mikrosatelit atau SSR (Simple Sequence Repeat) (untaian berulang sederhana), memiliki variasi yang luas dan menyebar luas dalam bentuk susunan yang panjang dari unit tandem yang pendek dan berulang di dalam genom (Jeffreys et al., 1985; Tautz dan Renz, 1984). SSRs ini menyediakan penanda Kodominan Mendelian yang sangat kuat dibandingkan marker Dominan sehingga dapat digunakan untuk membedakan struktur populasi genetik, kekerabatan, model reproduksi dan isolasi genetik (Queller, 1993, Taylor et al., 1999) Ketika dibandingkan dengan tipe penanda lainnya penanda SSR sangat akurat untuk karakterisasi genetik, seperti pada Aspergillus fumigates dan Saccharomycetes cerevisae (Bart et al., 2001, Perez et al., 2001), Phytophthora infestans (Lees, 2006), Magnoporthe grisea (Brondani , 2000, Kaye et al., 2003) dan oomycetes lainnya.

Perumal (2008) telah mendesain primer yang tepat dan dapat digunakan untuk penggandaan loci mikrosatelit yang telah diuji kemampuannya untuk membedakan patogenitas pada beberapa isolat P. sorghi dan untuk spesies patogen bulai lainnya seperti $P$. philipinensis, P. Maydis , P. sachari, Sclerospora graminicola dan $P$. sparsa. Dengan demikian primer ini

Agrovital | Jurnal Ilmu Pertanian Universitas Al Asyariah Mandar dapat digunakan didalam analisis kluster atau pengelompokan untuk menentukan keragaman genetik dan kekerabatan diantara beberapa spesies patogen bulai yang berbeda di beberapa lokasi di Indonesia.

Berdasarkan uraian di atas maka perlu dilakukan karakterisasi DNA pada Peronosclerospora spp. dari beberapa lokasi di Indonesia yaitu Medan, Kediri dan Maros dengan karakterisasi secara genetik berbasis SSR untuk menentukan keragaman genetik dan kekerabatan diantara beberapa spesies patogen bulai yang berbeda dan selanjutnya dapat menentukan spesies dan struktur populasinya untuk menjadi panduan didalam proses perakitan varietas jagung tahan bulai dan pemanfaatannya secara luas sebagai komponen pengendalian penyakit.

\section{Kerangka Teori}

Penyakit bulai telah dikenal di Indonesia pertama kali di Jawa tahun 1897, Jawa tengah (Raciborski, 1897), Jawa timur dan Yogyakarta (Raciborski, 1900). Selain di Jawa dan Madura penyakit ini juga dilaporkan menyerang di Aceh, Sumatera Utara, Palembang, Kalimantan Barat, Bali, Lombok, Sulawesi Selatan, Minahasa, Tidore, Ternate, Ambon, Flores dan Timor (Wakman, 1987/1988; Roelofsen, 1956; Rutgers, 1916; van Der Goot; 1935, 1936; van Hall 1918, 1919). Penyakit bulai juga ditemukan di Lampung pada musim tanam 1973 (Tantera, 1975).

Wakman dan Djatmiko (2002) melaporkan bahwa terdapat 10 spesies cendawan penyebab penyakit bulai, dan hanya 3 spesies yang telah diidentifikasi ada di Indonesia yaitu Peronosclerospora maydis (Java downy mildew), P.philippinensis (Philippine downy mildew) dan P.sorghi (Sorghum downy mildew). Peronosclerospora maydis merupakan salah satu penyebab bulai yang hanya menyebar di Indonesia (Shaw, 1978). P.philippinensis khusus terdapat di daerah Minahasa, Sulawesi Utara (Semangun, 2006). P.sorghi ditemukan dapat menginfeksi sorghum dan jagung (Williams, 1984). Wakman dan Hasanuddin (2003) menemukan konidia patogen bulai yang berbentuk oval dan menyerupai konidia P.sorghi di Karo, Sumatera Utara

\subsection{Gejala}

Penyakit bulai dapat menimbulkan gejala sistemik yang meluas keseluruh bagian tanaman dan dapat juga menimbulkan gejala lokal atau setempat. Hal ini tergantung dari meluasnya jamur penyebab penyakit dalam tubuh tanaman yang terinfeksi. Gejala sistemik hanya terjadi bila jamur dapat mencapai titk tumbuh (Semangun, 2006). 


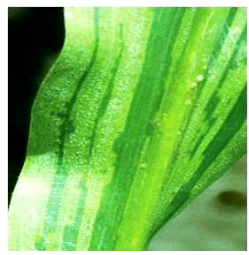

Gambar 1. Gejala Penyakit Java downy mildew Pada Tanaman Jagung

Tabel 1. Perkembangan gejala penyakit bulai (downy mildew)

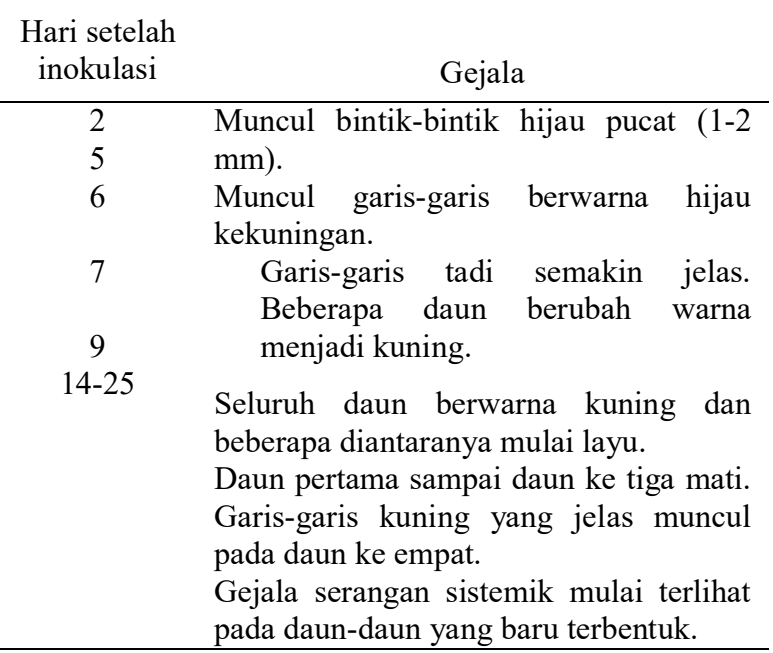

Sumber : Kajiwara (1974)

\subsection{Pengendalian}

Menurut Wakman (2008) untuk pengendalian penyakit bulai secara terpadu, hanya bisa dengan 4 (empat) komponen pengendalian lainnya yaitu: periode bebas tanaman jagung, penanaman jagung secara serempak pada satu hamparan, eradikasi tanaman terinfeksi bulai, menanam varietas jagung tahan penyakit bulai

\subsection{Isolasi DNA dan teknik PCR}

Isolasi DNA genom dilakukan dengan merusak sel atau dinding sel terlebih dahulu, hal ini dapat dilakukan dengan beberapa teknik, baik dengan menggunakan agensia hayati, bahan kimia, menggunakan enzim tertentu maupun secara fisik. Pemecahan sel dengan menggunakan enzim dapat dilakukan dengan menggunakan enzim lisozim yang dapat memecah dinding sel, senyawa lain yang biasa digunakan adalah CTAB (Cetyl Trimethyl Ammonium Bromide) (Yuwono, 2008).

Isolasi DNA dari organisme eukariot biasanya dilakukan melalui penghancuran sel (lisis), pemusnahan protein dan RNA, dan pemurnian DNA dengan memanfaatkan senyawa kimia seperti EDTA (Etilen Diamin Tetra Acetat) yang berfungsi merusak sel dengan cara mengikat ion magnesium, dan SDS (Sodium Dodesil Sulfat) yang merupakan sejenis deterjen untuk merusak membran sel sehingga dapat menyebabkan lisis pada sel. Protein dapat dibersihkan menggunakan larutan fenol (mengikat protein dan sebagian kecil RNA) dan kloroform (membersihkan protein dan polisakarida dari larutan). Protein juga dapat dihilangkan dengan bantuan enzim proteinase, dan RNA dapat dihilangkan dengan RNAse. Adapun ethanol serta $\mathrm{NaCl}$ berfungsi memekatkan, memisahkan DNA dari larutan dan mengendapkan DNA (Muladno, 2002).

Proses pemurnian dapat pula menggunakan Proteinase $\mathrm{K}$ dan RNAse untuk membersihkan protein dan RNA. Tahap ini juga memanfaatkan $\mathrm{NH}_{4} \mathrm{Ac}$ (Amonium Asetat) yang berfungsi untuk mengurangi terjadinya presipitasi sejumlah kontaminan. Tahap selanjutnya yaitu membersihkan kembali protein dan sejumlah RNA yang masih tersisa dengan menggunakan larutan fenol, kloroform dan isoamilalkohol (25:24:1) (Chisholm, 1992; Steen, 1999).

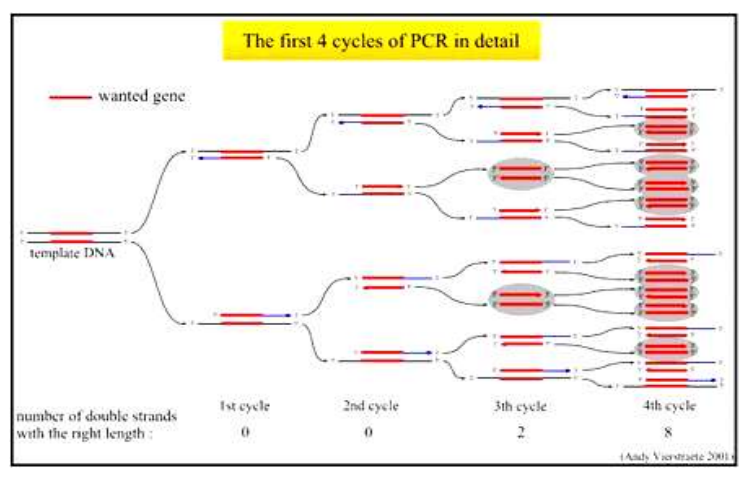

Gambar 2. Proses PCR untuk amplifikasi/perbanyakan DNA target dapat meningkatkan jumlah urutan DNA ribuan bahkan jutaan kali dari jumlah semula.

\subsection{Teknik Dasar dan Amplifikasi PCR}

PCR dilakukan dengan mencampurkan keempat komponen PCR dengan melalui proses (i) denaturasi dimana molekul DNA cetakan untainnya terpisah agar oligonukleotida primer dapat menempel $\left(95-100{ }^{\circ} \mathrm{C}\right)$ (Yuwono, 2008), (ii) annealing (penempelan) adalah proses penempelan primer (primer annealing) pada DNA cetakan $\left(50-60^{\circ} \mathrm{C}\right)$,(iii) extension (pemanjangan) dimana DNA mengalami pemanjangan dan kembali menjadi untaian ganda $\left(72{ }^{\circ} \mathrm{C}\right)$.

\subsection{Mikrosatelit atau SSR(Simple Sequance Repeat)}

Simple Sequence Repeats (SSRs) (Untaian berulang sederhana) atau mikrosatelit merupakan salah satu marka yang berdasarkan pada PCR dengan menggunakan primer yang menggabungkan sekuen komplementer spesifik dalam DNA sasaran (Rakoczy et al.,2004).

SSR ini menyediakan penanda Kodominan Mandelian yang sangat kuat dibandingkan marker Dominan dan dapat digunakan untuk membedakan struktur populasi genetik, kekerabatan, model reproduksi dan isolasi genetik (Taylor, et al., 1999) sehingga dapat digunakan untuk mendeteksi spesies yang berkerabat dekat secara lebih baik dibandingkan dengan markah molekuler yang lain (Santoso, 2008).

\subsection{Kemiripan Genetik Kaitannya dengan Populasi}

Spesies

Kemiripan genetik dari dua genotipe dapat diperkirakan secara tidak langsung dari data pedigree dan 
melalui markah molekuler (isozim, protein dan marka DNA). (Pabendon et al. tanpa tahun) Estimasi kedekatan genetik antara indifidu bermanfaat di dalam studi evolusi populasi atau spesies (Cox et al., 1985). Pabendon (2002) menyatakan bahwa jarak genetik dapat digunakan di dalam penentuan kelompok atau kluster yang didasarkan juga pada metode pautan rataan (average linkage) dengan memilih selisih jarak terbesar serta didukung oleh populasi asal genotip, selain itu juga didukung oleh hasil analisis bootstrapping kemudian ditarik garis memotong dendogram pada skala tingkat kemiripan genetic ( genetic similarity).

\section{Metode Pelaksanaan}

\subsection{Sampel Patogen}

Isolat merupakan koleksi laboratorium Biomolekular Balai Sereal Maros, Total 18 isolat Peronosclerospora spp yang digunakan yang berasal dari Kediri, Medan dan Maros. Isolat di ambil dari tanaman sakit yang berumur 3 minggu.

\subsection{Primer yang Digunakan}

Primer yang digunakan sebanyak 47 primer terdiri dari 14 primer (DM 1, DM 6, DM 20, DM 21, DM 23, DM 24, DM 32, DM 34, DM 36, DM 37, DM 38, DM 41, DM 43, DM 51) yang khusus untuk Peronosclerospora maydis dan 6 primer (DM 3, DM 10, DM 18, DM 22, DM 39, dan DM 50) khusus untuk $P$. philippinensis sedangkan terdapat 27 primer (DM 5, DM 7, DM 8, DM 9, DM 11, DM 12, DM 13, DM 14, DM 16, DM 19, DM 26, DM 27, DM 28, DM 30, DM 31, DM 33, DM 35, DM 40, DM 44, DM 45, DM 46, DM 47, DM 49, DM 52, DM 53, DM 54, dan DM 55) yang dapat digunakan untuk ketiga spesies

Tabel 2 Nama-nama isolat dan lokasi sampel pathogen

\begin{tabular}{|c|c|c|c|c|c|}
\hline No. & $\begin{array}{c}\text { Kode } \\
\text { sampel }\end{array}$ & Isolat & Lokasi & Varietas & $\begin{array}{c}\text { Intesitas } \\
\text { Serangan } \\
(\%)\end{array}$ \\
\hline 1 & KD-1 & Konidia & Kediri & Pioner 21 & 85 \\
\hline 2 & KD-2 & Konidia & Kediri & Pioner 21 & 85 \\
\hline 3 & KD-3 & Konidia & Kediri & Pioner 21 & 85 \\
\hline 4 & MD-1 & Konidia & Medan & $\begin{array}{l}\text { Pulut } \\
\text { harapan }\end{array}$ & 90 \\
\hline 5 & MD-2 & Konidia & Medan & $\begin{array}{l}\text { Pulut } \\
\text { harapan }\end{array}$ & 90 \\
\hline 6 & MD-3 & Konidia & Medan & $\begin{array}{l}\text { Pulut } \\
\text { harapan }\end{array}$ & 90 \\
\hline 7 & MR-1 & Konidia & Maros & Anoman & 100 \\
\hline 8 & MR-2 & Konidia & Maros & Anoman & 100 \\
\hline 9 & MR-3 & Konidia & Maros & Anoman & 100 \\
\hline 10 & KD-1 & Daun & Kediri & Pioner 21 & 85 \\
\hline 11 & KD-2 & Daun & Kediri & Pioner 21 & 85 \\
\hline 12 & KD-3 & Daun & Kediri & Pioner 21 & 85 \\
\hline
\end{tabular}

\begin{tabular}{|c|c|c|c|c|c|}
\hline 13 & MD-1 & Daun & Medan & $\begin{array}{l}\text { Pulut } \\
\text { harapan }\end{array}$ & 90 \\
\hline 14 & MD-2 & Daun & Medan & $\begin{array}{l}\text { Pulut } \\
\text { harapan }\end{array}$ & 90 \\
\hline 15 & MD-3 & Daun & Medan & $\begin{array}{l}\text { Pulut } \\
\text { harapan }\end{array}$ & 90 \\
\hline 16 & MR-1 & Daun & Maros & Anoman & 100 \\
\hline 17 & MR-2 & Daun & Maros & Anoman & 100 \\
\hline 18 & MR-3 & Daun & Maros & Anoman & 100 \\
\hline
\end{tabular}

\subsection{Isolasi Patogen}

Konidia dikumpulkan dari daun yang terinfeksi dengan langkah sebagai berikut : tanaman sakit yang berumur 3 minggu dicuci dengan air dingin kemudian dikering anginkan dan ditempatkan di dalam ember yang berisi air setinggi $1-2 \mathrm{~cm}$ sampai jam 8 malam. Kemudian disungkup dengan kantong plastik hitam, kemudian daun ditempatkan di dalam gelap sepanjang malam dengan suhu $23^{\circ} \mathrm{C}$. Kemudian pada pukul 04.00 spora dikumpulkan pada air steril dan konidia dicuci sekali dengan etanol $70 \%$ untuk digunakan pada ekstraksi DNA.

\subsection{Ekstraksi dan Isolasi DNA}

Proses isolasi DNA ini mengikuti prosedur Geoge (2004) dan Khan. Elektroforesis dan Visulisasi hasi PCR menggunakan Polyacrilamid Gel (PAGE), Deteksi Fragmen DNA Menggunakan Silver Staining

\subsection{Analisis Data}

Analisis data dilakukan berdasarkan nilai Analisis Tingkat Polimorfisme (Polimorphic Information Content - PIC

Genotip yang muncul dikelompokkan berdasarkan matriks kemiripan genetik melalui Unweighted Pair Group Method Using Arithmatic Average (UPGMA). Dendrogram dikonstruksi berdasarkan UPGMA dengan menggunakan koefisien Jaccard. Jarak matriks dan dendrogram dibentuk dengan menggunakan program NTSYS-pc (Numerical Taxonomic System) Versi 2.1 (Rohlf, 2000).

Hasil

\subsubsection{Profil Primer SSRs pada 9 Sampel Patogen Bulai yang Diidentifikasi}

Dari total 9 sampel DNA dari daun bergejala dan 9 sampel DNA dari konidia yang dianalisis diperoleh total 70 pita dengan jumlah rata-rata 4,7 pita untuk DNA dari daun bergejala dan 36 pita dengan jumlah rata-rata 5 pita untuk DNA dari konidia. Tingkat polimorfisme (Polymorphism Information Content $=$ PIC) berkisar antara $0,54-0,81 \%$ dengan rata-rata $0,7 \%$ untuk kedua sumber DNA. Gambar profil pita DNA dapat dilhat pada gambar 3 . 


\subsubsection{Analisis Kemiripan Genetik}

Analisis kemiripan genetik digunakan untuk menentukan hubungan kekerabatan secara genetik diantara 9 sampel patogen bulai yang diidentifikasi yang ditampilkan dalam bentuk dendrogram seperti gambar 3, melalui analisis NTSYS pc-2.1 Dendrogram tersebut dikonstruksi melalui UPGMA pada 15 primer SSR.

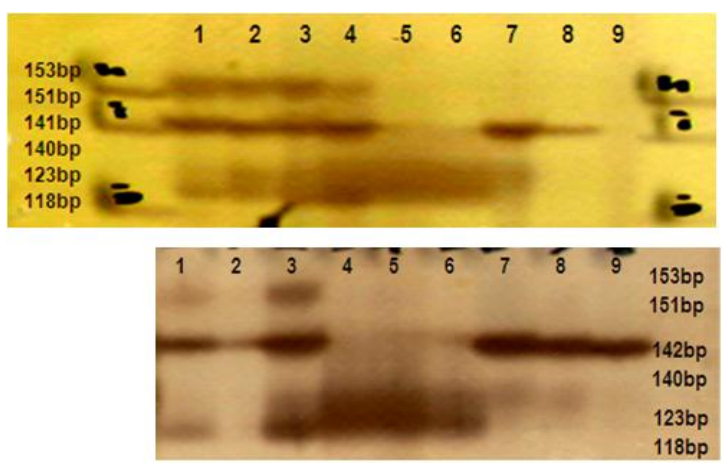

Gambar 3 :Profil DNA patogen Peronosclerospora spp dengan menggunakan primer SSRs DM14. Jalur 1,2,3 adalah DNA patogen bulai asal Kediri, jalur 4,5,6adalah DNA patogen bulai asal Medan dan jalur 7,8,9 adalah DNA patogen bulai asal Maros

Berdasarkan dendrogram isolat dari satu lokasi berada pada tingkat kemiripan yang sama dan masingmasing lokasi berada pada tingkat kemiripan yang berbeda dengan nilai tingkat kemiripan genetik berkisar antara 0,51-1,00 pada isolat yang berasal dari daun dan 0,54-1,00 pada isolat yang berasal dari konidia dengan skala tingkat kemiripan genetik 0,55 pada isolat asal daun dan 0,60 pada isolat asal konidia, sehingga terbentuk 3 kelompok atau kluster (Gambar 3 dan 4). Kelompok I, II dan III masing masing dengain nilai kemiripan genetik 1,00, antara kelompok I dan II memiliki nilai kemiripan genetik sebesar 0,55 pada isolat asal daun dan 0,60 untuk isolat asal konida, sedangkan antara kelompok I,II dengan kelompok III sebesar 0,51 pada isolat asal daun, dan 0,54 untuk isolat asal konida. tingkat konfidensi atau kepercayaan pengelompokkan dari hasil analisis bootstrapping mendukung nilai kemiripan berdasarkan UPGMA atau dendrogram. Setiap kelompok memiliki tingkat kepercayaan yang tinggi yaitu sbesar $100 \%$ dan pengelompokkan antara kelompok I, II dengan kelompok III memiliki tingkat kepercayaan $51,9 \%$ pada sampel bulai dari daun dan $68,1 \%$ untuk sampel bulai dari konidia.

Agrovital | Jurnal Ilmu Pertanian Universitas Al Asyariah Mandar

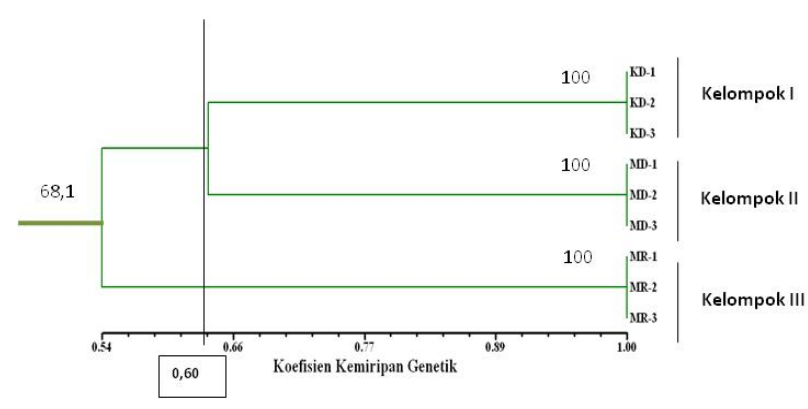

Gambar 4: Dendrogram keragaman genetik isolat Peronosclerospora spp. yang diperoleh dari sampel daun dan berasal dari Kediri (KD), Medan (MD) dan Maros (MR) berdasarkan 15 primer SSR dan dikonstruksi berdasarkan koefisien kemiripan Jaccard. Nilai di atas garis menunjukkan tingkat kepercayaan pengelompokan yang diperoleh melalui analisis bootstrapping

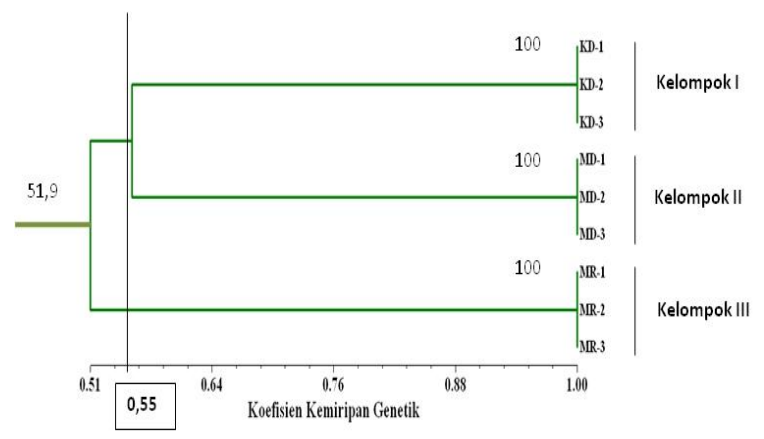

Gambar 5: Dendrogram keragaman genetik isolat Peronosclerospora spp. yang diperoleh dari sampel Konidia dan berasal dari Kediri (KD), Medan (MD) dan Maros (MR) berdasarkan 7 primer SSRs dan dikonstruksi berdasarkan koefisien kemiripan Jaccard. Nilai di atas garis menunjukkan tingkat kepercayaan pengelompokan yang diperoleh melalui analisis bootstrapping

\section{Pembahasan}

Nilai kemiripan gentik pada kelompok I dan II sebesar 0,55 dan kelompok III sebesar 0,51. Hal ini menunjukkan bahwa kekerabatan antara kelompok I dan II lebih dekat dibandingkan dengan kelompok III memiliki kekerabatan yang lebih jauh. Nilai similaritas yang semakin mengecil dari kelompok I ke kelompok III menunjukkan hubungan kekerabatan yang semakin jauh, sehingga memiliki kemungkinan adalah isolat pada kelompok I adalah spesies P.maydis dan kelompok II adalah spesies P.sorghi dan kelompok III adalah isolat P. philippinensis. Hal ini sejalan dengan hasil penelitan Perumal et al., 2008 menunjukkan bahwa Kelompok I yang terdiri dari P. sorghi memiliki nilai similaritas 0,90 , kelompok II yang terdiri dari isolat P. maydis dan P. scchari dengan nilai similaritas 0,85 dan $\mathrm{P}$. 
philippinensis yang berdir sendiri memiliki nilai similaritas 0,77 yang juga memiliki nilai similaritas yang semakin jauh antara kelompok.

Adanya perbedaan profil sidik jari DNA dan morfologi dari masing-masing isolat dengan lokasi yang berbeda dapat digunakan sebagai alat diagnosa didalam strategi pemuliaan untuk mendapatkan tanaman yang resisten terhadap penyakit bulai dan dapat juga untuk dijaadikan alat memonitoring munculnya ras virulensi bari dari patogen. Hal ini juga menunjukkan metode pengendalian yang diterapkan disuatu lokasi belum tentu dapat dikembangkan di lokasi yang lain, sehingga metode pengendalian yang digunakan harus bersifat spesifik lokasi. Hal ini disebabkan dengan adanya perbedaan karakteristik patogen pada lokasi yang berbeda mengarah pada perbedaan spesies dan tingkat virulensi patogen di dalam menyebabkan penyakit bagi tanaman.

\section{Kesimpulan}

Berdasarkan hasil penelitian yang telah dilakukan secara karakterisasi molekuler maka dapat dibuat kesimpulan bahwa keragaman genetik yang diperoleh membentuk 3 kelompok, kelompok I adalah isolat asal Kediri yang merupakan $P$. maydis, kelompok II adalah isolat asal Medan yeng merupakan P. sorghi dan kelompok III adalah isolat asal Maros adalah $P$. philippinensis.

\section{Daftar Pustaka}

Alberts, B., Johnson, A., Lewis, J., Raff, M., Roberts, K., Walter, P., 2002. Molecular Biology of the Cell. Edisi ke-4. Garland Science: New York.

Bart-Delabesse E, J. Sarfati, J.P. Debeaupuis, W Leeuwen van, A, Belkum van, S. Bretagne, J.P. Latge, 2001. Comparison of Restriction Fragments Length Polymorphism, Microsatellite Length Polymorphism, and Random Amplification of Polymorphic DNA Analyses Fingerprinting Aspergillus fumigatus Isolates. J Clin Microbiology, 39:2683-2686.

Bock C, Jeger M, Mughogo L, Mtisi E, Cardwell KF, 1998. : Production of conidia by Peronosclerospora sorghi in Zimbabwe. Plant Pathology 1998, 47:243-251.

Bock, C.H., Jeger, J.J., Mughogho, L.K., Cardwell, K.F., Mtisi, E., Kaula, G., and Mukansabimana, D. 2000. Variability of Peronosclerospora sorghi isolates from different geographic locations and hosts in Africa. Mycological Research 104 61-68.

Brondani C, Brondani RPV, Garridon LR, Ferreira ME, 2000. Development of microsatellite markers for genetic analysis of Magnaporthe grisea. Genetica Moleculer Bioogyl, 23:753-762.

CIMMYT, 2010. Downy mildew (extended information)

http://maizedoctor.cimmyt.org/index.php?id=23 3\&option=com_content\&task=view. Diakses Desember 2010 .
Jeffreys AJ, Wilson V, Thein SL, 1985. Hypervariable 'Minisatellite' Regions in Human DNA. Nature, 314(6006):67-73.

Kajiwara T. 1974. Some Experiments on Downy Mildew of Maize. Proc. Symposium on Downy Mildew of Maize, Tokyo. Trop. Agric. Res., Series No. 8:121-123.

Kaye C, Milazzo J, Rozenfeld S, Lebrun MH, Tharreau D, 2003. The development of simple sequence repeat markers for Magnaporthe grisea and their integration into an established genetic linkage map. Fungal Genet Biol, 40(3):207-214

.Lees AK, Wattier R, Shaw DS, Sullivan L, Williams NA, Cooke DEL, 2006. Novel Microsatellite Markers for the Analysis of Phytophthora infestans Populations. Plant Pathology, 55:311-319.

Muladno, 2000.,Tekhnologi Rekayasa genetika. Pustaka Wira Usaha Muda dan ESESE, Bogor.

Pabendon,M.B., 2002. Identifikasi Genotip Jagung ke dalam Kelompok Heterotik Melalui Marka SSRs(Simple Sequence Repeats) Kaitannya dengan Penentuan Tetua Hibrida. TESIS, Universitas Padjadjaran Bandung

Perez MA, Gallego FJ, Martinez I, Hidalgo P, 2001. Detection, Distribution and Selection of Microsatellites (SSRs) in the Genome of the Yeast Saccharomyces cerevisiae as Molecular Markers. Lett Appl Microbiol, 33:461-466.

Perumal R, Isakeit T, Menz M, Katile S, No EG, Magill $\mathrm{CW}$, 2006. Characterization and Genetic Distance Analysis of Isolates of Peronosclerospora sorghi Using AFLP Fingerprinting. Mycological Research, 110(4):471-478.

Perumal R., Padmavathi N., Saradha R.E,Eun-Gyu No, Umesh K. R., Louis K. P., Gary N. O.,Douglas G.L. and Clint W M., 2008. Simple Sequence Repeat Markers Useful for Sorghum Downy Mildew (Peronosclerospora sorghi) and Related Species. BMC Genetics. http://www.biomedcentral.com/1471-2156/9/77. diakses tgl 16 Desember 2010.Queller, 1993.

Rakoczy, M. T., and Hanna Bolibok, 2004. Characteristics and a Comparison of Three Classes of Microsatellite-based Markers and their Application In Plants. Cellular \& molecular biology letters Volume 9, (2004): 221 -238 http://www.cmbl.org.pl.

Santoso, T.J., W.U. Dwinita, , dan M.S. Endang 2008. Analisis Sidik Jari DNA Plasma Nutfah Kedelai Menggunakan Markah SSR. Balai Besar Penelitian dan Pengembangan Bioteknologi dan Sumberdaya Genetik Pertanian. Bogor.

Semangun, H., 2006. Pengantar Ilmu Penyakit Tumbuhan. Gadjah Mada University Press.

Shaw, C.G, 1978. Peronosclerospora Species and other Downy Mildews of the Gramineae. Mycologia, 70:594-604.

Smith, J.S.C., E.C.L. Liu, H. Shu, O.S. Smith, S.J. Wall, M.L. Senior, S.E. Mitchell, S. Kresovich dan 
J.Ziegle, 1997. An Evaluation of the Utility of SSR Loci as Moleculer Marker in Maize (Zea mays L.): Comparison with Data from RFLPs and Pedigree. Theor. Appl. Genet. 95:163-173.

Steen, S.W., 1999. Handbook for DNA Isolation RAPD-PCR and PCR-RFLP. Botanical Garden and Museum. University of Oslo

Sudjono, M.S., dan Y. Sopandi. 1988. Pendugaan penurunan hasil jagung oleh penyakit bulai (P. maydis Rac. Shaw.). Seminar Balittan Bogor tahun. 7 hal.

Tautz D, Renz M, 1984. Simple sequences are ubiquitous repetitive components of eukaryotic genomes. Nucleic Acids Res 12(10):4127-4138.

Taylor JW, Jacobson DJ, Fisher MC, 1999. The Evolution of Asexual Fungi: Reproduction, Speciation and Classification. Annu RevPhytopathol, 37:197-246.van Der Goot; 1935, 1936;

Wakman, W. dan H.A. Djatmiko. 2002. Sepuluh Spesies Cendawan Penyebab Penyakit Bulai pada Tanaman Jagung. Makalah disajikan pada Seminar PFI di Purwokerto 7 September 2002. 10.

Wakman, W., S. Asikin, A. Bustan, dan M.Thamrin, 2006. Identifikasi spesies cendawan penyebab penyakit bulai pada tanaman jagung di Kabupaten Tanah Laut Propinsi Kalimantan
Selatan. Seminar Mingguan, Balitsereal. Jumat, 30 Juni 2006.

Wakman, W., 2008. Pengendalian Penyakit Bulai pada jagung di bengkayang kalbar. Prosiding Seminar Ilmiah dan Pertemuan Tahunan PEI PFI XIX Komisariat Daerah Sulawesi Selatan, 5 Nopember 2008 on line http://www.peipfikomdasulsel.org/wp-content/uploads/2011/06/8WASMO-Pengendalian-Penyakit-Bulai-Pada79-85.pdf. diakses 15 juli 2011

Wiliams, R.J., 1984. Downy Mildews of Tropical Cereals. Pages 1-103 in Advances in Plant Pathology. Volume 2 (Ingrams, D.S., and Wiliams, P.H., eds.). London, UK: Academic Press.

Yao C, Frederiksen RA, Magill CW, 1992. Length heterogeneity in ITS 2 and the methylation status of CCGG and GCGC sites in the rRNA genes of the genus.Perosclerospora. Current Genetics 22:415-420

Yasin, M.S., Soertiningsih, Tenriware.A., Adnan. A.M., Wakman.W., Tolanca.A.H. dan Syafruddin, 2008. Petunjuk Lapanga Hama, Penyakit dan Hara pada Jagung. Pusat Penelitian dan Pengembangan Tanaman Pangan. Badan Penelitian dan Pengembangan Pertanian.

Yuwono Tribowo, 2008. Bioteknologi Pertanian. Gadjah Mada University Press, Yogyakarta. 